\title{
O TEATRO, A ESCOLA E O JOVEM ESPECTADOR ${ }^{1}$
}

\section{Teatro amplia experiência cognitiva e emocional do espectador através de trabalho pedagógico específico}

Houve um tempo em que o teatro era o lugar exclusivo dedicado à ficção. Atualmente, as mídias eletrônicas produzem ficção a um ritmo frenético, ou melhor, elas traduzem a realidade em ficção e a ficção em realidade, alterando assim os campos de percepção visual do espectador.

Nesse contexto, a criança é espectadora desde seu nascimento; um espectador que a quantidade de imagens e a qualidade de sua emissão, bem como a facilidade aparente de sua decodificação induzem a uma atitude de fruição superficial e desatenta, ou seja, passiva. O que significa dizer que quanto mais o olho consome as imagens, mais ele parece perder - ou pelo menos atenuar - sua capacidade de registro e avaliação.

Um tal olhar é inadequado à recepção teatral. Se não é mais o lugar exclusivo da ficção ${ }^{2}$, o teatro, entretanto, continua sendo o lugar no qual o processo ficcional se realiza aqui e agora, o lugar no qual as imagens, para serem interpretadas como signos e memorizadas em sua seqüência, exigem um olhar atento, paciente, apaixonado.

Diferentemente do que ocorre na televisão, no cinema ou nas histórias em quadri- nhos, que determinam a visão do espectador pela escolha do enquadramento e oferecem primeiros planos ou planos de conjunto como chaves de leitura, no teatro a cena se oferece ao olhar em sua totalidade e sua complexidade, e é o olho que deve escolher seu ponto de vista e seu percurso. É bem o tipo de olhar que preside o consumo estético que Matisse definiu como operação criadora que exige um esforço - e que contrasta com a recepção inconsciente e casual que caracteriza o consumo de imagens próprio de nossa videocultura deste fim de século.

Por outro lado, é ao teatro que pertence, desde sempre e de modo essencial, o caráter de festividade cujo mistério, diz Gadamer, é a calma suspensão do tempo ${ }^{3}$ vinculada a suas antigas origens rituais. Esse tempo forte do teatro, essa festa de experimentação não é fácil de descobrir no contexto da sociedade do espetáculo, cujo tempo resulta diluído em uma continuidade sem cesura ou sobressalto.

\section{A AUTORA}

\section{Mafra Gagliardi}

Professora do Departamento de Ciência da Educação da Universidade de Padova, Itália.

1. Do original Un oeil voit, l'autre sent. Pour une pedagogie du jeune spectateur. Tradução: Profa. Silvana Garcia, EAD-ECAUSP.

2. GIACCHÉ, P. G. Tra realtà e funzione. In: Lo spettatore partecipante. (Entre a realidade e a ficção. In: O espectador participante). Milano: Guerini Studio, 1991. p. 55-84.

3. GADAMER, Hans Georg. L'attualità del bello. (A atualidade do belo). Texto de conferência proferida pelo autor em 1954, por ocasião do $175^{\circ}$ aniversário da inauguração do Teatro Nacional de Mannheim. 
Dewey ${ }^{4}$ já sustentava que a capacidade de relacionar-se com a arte não é absolutamente inata, mas é o resultado de uma ginástica mental que só pode nascer sob o efeito de uma estimulação apropriada, de um projeto educativo corretamente formulado. Com maior razão, fica evidente, nos dias de hoje, que a abordagem da arte, notadamente da arte teatral, deve vincular-se a uma ação educativa, entendida, em primeira instância, como alfabetização em linguagens artísticas e iniciação ao comportamento estético.

A obra fala por si mesma, se ela tem com quem falar. Mas, para que o diálogo possa se instaurar, é preciso justamente preparar o interlocutor, cuja resposta - de maneira específica na arte teatral - é essencial para a concretização das potencialidades semânticas e comunicativas da representação.

Em resumo, quero dizer que a educação do jovem espectador começa anteriormente a seu encontro efetivo com o espetáculo e que ela se inscreve em um contexto mais geral.

O que se deve entender, portanto, por educação do jovem espectador?

O tema é complexo e creio que não foi ainda suficientemente explorado, tanto no âmbito da reflexão teórica quanto no das aplicações práticas.

Antes de mais nada, devo esclarecer que quando emprego o termo educação não pretendo em absoluto me referir a uma escolarização do teatro, ou seja, à sua introdução nos currículos escolares como disciplina a ser ensinada paralelamente às outras.

A competência do jovem espectador, em um patamar básico - como é aquele que tratamos aqui - deve ser entendida não tanto como conhecimento da história do teatro e de seus códigos expressivos, mas sobretudo como um savoir-faire, isto é, como a soma das habilidades e aptidões que lhe permitem realizar as diferentes operações receptivas.

Jamais deveríamos exigir do teatro que ele se faça didático, portador de noções ou de ensinamentos moralizantes. Ou, pior ainda, que ele se torne o objeto de exercícios escolares propostos como verificação da eficiência de sua recepção.

\section{AMPLIAR A INICIATIVA INFANTIL}

Bem ao contrário, quando se realiza uma escolarização desse tipo, a experiência teatral se esvazia de toda significação e de todo prazer. Já o fato de que, hoje, o público infantil seja em grande parte um público obrigado (quer dizer, integrado na organização escolar que decide os tempos e as modalidades de lazer) acarreta, na minha opinião, uma série de elementos negativos sobre os quais devemos refletir. A tendência atual, na verdade, é a de se propor espetáculos para o público jovem fora do horário escolar, em centros polivalentes reservados ao tempo livre, onde os jovens podem escolher entre as diferentes formas de arte que lhes são oferecidas, do cinema à música, à literatura.

Quero dizer que o papel da escola com relação ao teatro é fundamental nessa primeira fase, pois só a escola pode desenvolver um trabalho de alfabetização artística e oferecer a oportunidade de uma aproximação com a experiência teatral $a$ todas as crianças, independente de suas diferenças socioculturais e econômicas - diferenças essas que, como se sabe, têm uma forte influência sobre a freqüência do espectador adulto nas salas de teatro.

A escola, porém, não pode ter um papel hegemônico: é preciso ampliar o espaço 
da iniciativa infantil, permitindo às crianças a possibilidade de ter acesso direto ao teatro e escolher os espetáculos aos quais desejam assistir.

É evidente, no entanto, que a escola, ao assumir a educação do jovem espectador, deve abrir-se a óticas diferentes daquelas que presidem habitualmente o processo educativo. A instituição escolar, constitucionalmente voltada à taxonomia, aos conhecimentos classificatórios, parece privilegiar um saber científico - para usar uma definição de Lyo$\operatorname{tard}^{5}$ - que se vincula essencialmente a uma linguagem denotativa, pela qual é possível uma única relação unívoca entre significante e significado. Quando se trata da educação estética, encontramo-nos mais na esfera do saber narrativo, que recorre a uma linguagem conotativa, caracterizada pela ambigüidade e interpretabilidade dos significados.

Subjugada pelos estereótipos propostos pela mídia e pelo saber científico sustentado pela escola, a criança, quando assume o papel de espectador, deve poder experimentar um status diferente. Deve se apropriar do estupor, termo que devemos entender no sentido de reviravolta de sua maneira de ver e escutar, de momento de crise entendido como proposta de uma leitura estupefaciente do real: daquilo que até então era lido de maneira denotativa (através das explicações) e que requer, no presente, uma abordagem de tipo conotativo, por meio da metáfora, da metonímia, do símbolo, instaurando assim uma relação complexa entre significados e significantes ${ }^{6}$.

Essa leitura estupefaciente procede do ato perceptivo do olhar que apreende as for- mas da cena seguindo parâmetros de prazer/recusa, estabelece relações e referências entre as imagens em movimento e contém em si os elementos que serviram a uma primeira apreciação.

No plano educativo, trata-se agora de se mover em direção àquilo que eu chamaria de uma ecologia da percepção e de promover a descoberta de todas as ressonâncias profundas da experiência de visão e de escuta. Trata-se de guiar as crianças para ensiná-las a "pôr-se à escuta do olhar" , em um duplo movimento que se adianta para frente, no registro das imagens que, então, se oferecem na cena, bem como para trás, na regressão confiada à memória.

\section{UM OLHO VE, O OUTRO SENTE}

É ao ato perceptivo da visão que se refere Paul Klee quando diz um olho vê, o outro sente e quando observa: "ver tende à identificação da forma... sentir evoca, ao contrário, seu interior e sua constituição secreta"8. Esse "sentir", na acepção de Paul Klee, assemelha-se ao fundamento do comportamento estético. A etimologia do termo remete ao grego aistheticos, que significa "sensível, capaz de sentir", e que pertence ao mesmo campo léxico e semântico de aisthanomai, que significa "sinto, percebo com os sentidos; vejo, entendo, sinto, aprendo, percebo, compreendo".

Portanto, se o comportamento estético é "sentir, perceber os sentidos", é também "aprender e compreender qualquer coisa que foi produzida, sobre a mesma base sen-

5. LYOTARD, Jean Françoise. A condição pós-moderna. 2ed. Lisboa: Gradiva, 1989.

6. DALLARI, M. Guardare intorno. (Examinar em torno). Firenze: La Nuova Itália, 1986.

7. GROSJEAN, A. A l'écoute du regard ou de quelques procedures de lecture critique du jeu dans le domaine du théâtre-éducation. Théâtre-éducation. L'école du spectateur. (Do ouvir ao olhar ou alguns procedimentos de leitura crítica do jogo no domínio do teatro-educação. Teatro-educação. Escola do espectador). N.4, juillet, 1996. p.22-23.

8. CORTENOVA, M. Dal testo di una lezione tenuta al Bauhaus. Paul Klee. Catalogo della Mostra. (Do texto de uma lição completa ao Bauhaus. Paul Klee. Catálogo da Mostra). Mazzotta, 1992. 
sorial e intelectiva, de um modo articulado e ordenado, isto é, artisticamente" 9 .

É desse sentir que pode nascer, para o espectador, a possibilidade de entrar em contato com a significação profunda da obra e experimentar a emoção que leva a esses processos de identificação e de projeção vinculados aos aspectos temáticos do espetáculo teatral.

No domínio da educação - e de uma maneira geral na nossa cultura - existe ainda uma espécie de analfabetismo difuso no que concerne à experiência emocional $\mathrm{e}$ às suas modalidades de comunicação.

Em geral, opõe-se a emoção à elaboração lógico-conceitual, desvalorizando a primeira em favor da segunda e, conseqüentemente, desvalorizando também esses domínios (entre eles o teatro) para os quais se atribui, equivocadamente, um impacto emotivo totalizante e exclusivo. No entanto, as pesquisas mais recentes efetuadas no domínio das neurociências ressaltam que "os processos cognitivos e os processos emocionais utilizam os mesmos circuitos neurônicos e são inseparáveis"10.

Naquilo que concerne especificamente ao teatro, adverte-se contra a dicotomia despótica entre cognitivo e emotivo e sustentase que na experiência estética as emoções funcionam cognitivamente, seja porque resultam determinadas, ao menos em parte, pelos processos cognitivos, seja porque contribuem para fazer do espetáculo uma experiência conceitual.

Em resumo, a experiência teatral, como experiência estética, "deve ser concebida (e as primeiras verificações empíricas revelam isso) como um conjunto complexo de processos perceptivos, interpretativos, emotivos, apreciativos e mnemônicos que interferem e interagem" 11 .

Contudo, não se pode esquecer de que a criança é portadora de uma cultura totalmente diferente daquela do adulto e que sua história, sua linguagem, sua experiência intervêm nas respostas que dá ao espetáculo. Como espectador a ela deve ter a liberdade de recusar a interpretação preconcebida do adulto, de operar relações de inferência e de estabelecer associações com sua própria visão do mundo.

É possível encorajar essa resposta se lhe oferecemos o meio de experimentar, além do papel de sujeito receptor, o papel de sujeito emissor da linguagem teatral, segundo uma lógica de intercâmbio no plano comunicativo que a institui como produtor autônomo e consciente da comunicação.

De imediato, a partir do momento em que a escola escolhe adotar a arte teatral como fonte de formação e de educação estética, ela deve oferecer as condições necessárias para também tornar-se ateliê, no qual seja possível experimentar a alternância entre ver e fazer, numa tensão dinâmica contínua entre os dois pólos.

A título de conclusão, quero apresentar brevemente um projeto de educação do jovem espectador que realizei, de modo a ilustrar as reflexões aqui expostas.

O projeto, ainda em fase experimental, compreende quatro ateliês diferenciados segundo os segmentos de idade e dirigidos por mediadores que detêm funções diversas.

Os ateliês consagrados às crianças das escolas maternais e das escolas primárias concentram-se na preparação de um clima de expectativa com relação ao espetáculo, na fo-

9. ARGENTON, A. Arte e cognizione. (Arte e cognição). Milano: Raffaello Cortina Editore, 1996.

10. CONTINI, M. G. Per una pedagogia delle emozioni. (Por uma pedagogia da emoção). Firenze: La Nuova Italia, 1992.

11. MARINIS, M. de. Capire il teatro. Lineamenti di una nuova teatralogia. (Compreender o teatro. Delineando um novo conhecimento do teatro). Firenze: La Casa Husher, 1988. 
calização do olhar, na percepção visual e na memorização. Nos ateliês, estimulamos as crianças, por intermédio de atividades lúdicas e técnicas pictóricas, a reelaborarem criativamente cenas, objetos e personagens do espetáculo a que acabaram de assistir. As proposições/estímulos formulados pelos mediadores variam, a cada vez, em função do espetáculo escolhido: por exemplo, damos às crianças pequenas teatros feitos com caixas de papelão, com os quais brincam, colocando nelas personagens ou objetos de cenografia que desenham, reconstruindo, assim, in micro, o espaço tridimensional da cena. Ou fazemos com que ouçam o registro da música que acompanhou o espetáculo e as incitamos a desenhar livremente, sobre grandes tiras de papel, as sugestões que lhe ocorrem. Às vezes, por sua vez, um artista adulto também elabora sua própria interpretação do espetáculo, mesmo em linguagem pictórica abstrata.

Após um espetáculo de sombras, as crianças construíram, com um papelão negro, um espaço circular no qual cada uma recortou a forma de um raio de luz e uma imagem que tenha impressionado seu olhar. Essa espécie de cabana de pequenas janelas múltiplas tornou-se, em seguida, um espaço para o jogo e para o intercâmbio de histórias. Em geral, após o ateliê, as crianças continuam a desenhar espontaneamente durante muito tempo as imagens do espetáculo. Da maioria do material produzido aflora uma forma de pensamento visual que desprende os elementos estruturais das cenas, os quais, ao serem representados, evidenciam formas, relações, funções. Às vezes, as crianças desenham também objetos que não estavam presentes no palco, mas que imaginaram graças às palavras e gestos dos atores.
A recepção do espetáculo e o prazer que daí decorre se desenrolam na dialética entre percepção e imaginação.

Parece, portanto, que esta forma de atividade contribui para focalizar o olhar do jovem espectador sobre as formas da cena e a concentrar sua atenção sobre a ressonância que a experiência teatral suscita nele.

Um outro ateliê, dirigido a uma classe piloto do colégio, pretende focalizar especificamente o processo interpretativo do jovem espectador. Para criar um clima de expectati$v a$, na semana que antecede à apresentação de um espetáculo o grupo envia à classe uma carta convite com textos apropriados, visando a estimular a curiosidade do jovem espectador e despertar seu interesse.

Em seguida, após o espetáculo, a classe se reúne com os atores para ter com eles um diálogo aprofundado. Se a mediação do diretor e dos atores ajuda a tornar inteligível certas passagens obscuras do espetáculo, pode também evidenciar uma distância entre o que os atores querem expressar e as significações efetivamente percebidas pelos espectadores. De volta à classe, os jovens se dedicam a práticas de escritura criativa e de brainstorming 12 .

Um último ateliê é destinado aos educadores. Partindo de um experiência individual de espectador adulto, aprofunda-se o papel da percepção, da emoção e da memória nas dinâmicas de recepção teatral. Sobretudo, busca-se trazer à consciência o valor de uma relação com a arte - notadamente com a arte teatral - que seja fruto de uma educação da visão e da escuta, não menos que de uma pedagogia das emoções.

12. Termo utilizado para significar o exercício da manifestação livre e torrencial de idéias, para posterior seleção, aprimoramento e organização. 
Resumo: 0 artigo trata do teatro como linguagem ficcional e estética que amplia a capacidade cognitiva e emocional dos espectadores, sejam eles crianças, jovens ou adultos. Mostra como a escola pode desempenhar importante papel ao tornar o teatro acessível às crianças de diferentes níveis socioeconômicos, desenvolvendo um trabalho de alfabetização artística e possibilitando aproximação com a experiência teatral. A autora propõe uma pedagogia para o jovem espectador e dá exemplos de ateliês que podem ser desenvolvidos no espaço escolar.

Palavras-chave: teatro, escola, experiência teatral, experiência estética, espectador, recepçăo
Abstract: The article treats theater as a fictional and aesthetic language that enhances the spectator's cognitive and emotional capability, whether they are children, young people or adults. It exemplifies how the school can have an important role by bringing the theatre within the reach of children of different social and economic levels, developing an artistic literacy role and offering an approximation to the theatric experience. The author proposes a teaching method for the young spectator and gives examples of ateliers that may be set up in the school.

Key words: theatre, school, theatric experience, aesthetic experience, spectator 